\title{
CERBE
}

Center for Relationship Banking and Economics Working Paper Series

\section{Credit Rationing and the Relationship Between Family Businesses and Banks in Italy}

\author{
Giovanni Ferri, \\ Pierluigi Murro and \\ Marco Pini \\ Working Paper No. 24 \\ March 2018
}




\title{
Credit Rationing and the Relationship Between Family Businesses and Banks in Italy
}

\author{
Giovanni Ferri $^{*}$, Pierluigi Murro**, Marco Pini ${ }^{* * *}$
}

\begin{abstract}
We investigate whether family businesses (FBs) suffer stiffer credit rationing in the post-crisis Italian economy. FBs are, in fact, typically more opaque than other firms, possibly deterring bank lending to them. Moreover, regulatory changes may lead many banks to abandon relationship lending, weakening their ability to evaluate opaque firms. Using detailed firm data, our estimates reach nuanced conclusions. First, credit rationing is not more intense at FBs. However, it systematically intensifies if FBs engage in firm-bank arrangements less able to overcome information asymmetries either coupling with a main bank that uses transactional lending or diluting relationships across various banking partners.
\end{abstract}

JEL Classification codes: D22, G32.

Keywords: Family firms, Firm-bank relationships, Bank lending technologies, Credit rationing.

\section{Introduction}

Family businesses (FBs) are viewed with a degree of suspicion. Their family-based governance is often deemed to obstacle their ability to grow as well as to innovate and to export. Yet, FBs represent the backbone of Italy's productive system (see, e.g., Bianchi and Bianco, 2008; Minetti et al., 2015b). In this respect, drawing on data published by Mandl (2008) one can try to measure the importance of family businesses in almost all countries of the European Union. In terms of percentage of total enterprises, the phenomenon looks quite important. It emerges that, in all the 19 EU countries for which it is possible to build the index, the estimation on the presence of family businesses is about $2 / 3$ or higher. In terms of individual countries, the index reaches maximum values, above $90 \%$, for Germany and Italy. Even more important is, however, the share of employees that belong to FBs in total employees. This comparison - which is only possible for 12 of the 19 countries considered above - confirms and emphasizes the importance of family businesses in Italy, where FBs' share would stand above 90\%. In turn, Ferri et al. (2014) perform an in depth analysis of the extent of FBs in Italy - relying on some rather conservative assumptions and conclude that they represent at least $60 \%$ of employees in the industry and services sectors. This would amount to a much bigger FB share in Italy than the $27 \%$ estimated in 2000 for the U.S.

\footnotetext{
* LUMSA University, CERBE and MoFIR; ${ }^{* *}$ LUMSA University and CERBE, e-mail: p.murro@lumsa.it (Corresponding author); ${ }^{* * *}$ Unioncamere-Si.Camera.

The views put forward in the paper belong exclusively to the authors and do not involve in any way the institutions of affiliation.
} 
by Astrachan and Carey Shanker (2003). Moreover, some studies find Italian FBs to be more resilient than other firms to the crisis as well to have managed to shed employment less than nonfamily firms (see e.g., D’Aurizio et al., 2014).

A key question is whether banks can sustain FBs in the context of the prolonged crisis with feeble recovery experienced by the Italian economy. We should notice, in fact, that FBs are typically more opaque than other firms (Bianco et al., 2013). Their family-based governance often leads FBs to hold assets outside firms' perimeter thus making business statements less meaningful. Then, two chief factors might make banks reluctant to supply credit to FBs. First, since the weak recovery keeps credit risk levels still high, banks may be less willing than usual to lend to FBs because of their opaqueness. Second, regulatory changes seem to be attracting banks towards financial investment in lieu of making traditional credit and, linked to that, many banks may be abandoning their relationship lending model. As a result, the banks themselves may be becoming less able to deal with opaque firms, like the FBs. Besides, some FBs might engage in multiple banking relationships, which could dilute the ability of their banking partners to pierce the fog of asymmetric information and intensify credit rationing to those businesses.

By using a detailed and freshly assembled database derived from an extensive survey to firms, we construct self-reported measures of credit rationing and lending technologies and we test the two hypotheses above. Namely, (i) are banks less willing to lend to FBs?, and (ii) is credit rationing more intense for a FB that either couples with a main bank using transactional lending technologies or dilutes its relationships across various banking partners? Largely, our estimates fail to confirm the first hypothesis but do provide evidence consistent with the second hypothesis.

In the remainder of this chapter, Section 2 synthesizes the most relevant extant literature. In Section 3, we describe our data and methodology, followed by the presentation and comment of our regression analysis (Section 4). Section 5 contains the main conclusions and the discussion of some policy implications.

\section{Literature review}

\subsection{Family firms and credit availability}

The literature on the credit rationing of family firms is poor and does not provide clear evidence: there is a general presumption that FBs should be disadvantaged in their access to credit because of higher opaqueness and agency problems, but the supporting evidence of that presumption is at best ambiguous.

On one hand, in fact, it is often recognized that family ownership intensifies firms' opaqueness and/or agency problems, which should then more likely deliver asymmetric information-driven 
credit rationing for FBs. For the U.S., Anderson et al. (2009) find that, in large, publicly traded companies, firms having as controlling shareholder a founder and/or a founder's heir are significantly more opaque than diffuse shareholder firms. ${ }^{1}$ This is consistent with Schulze at al. (2003)'s hypothesis that parents' altruism could obstacle replacing inefficient heir-managers in FBs, and with the findings of Steijvers et al. (2010) that, fearing the negative performance consequences of failing to replace those inefficient managers, lenders ask FB's to pledge more collateral. On a large sample of French small businesses Hamelin (2013) argues that the significantly lower growth of FBs is partly explained by the fact that the higher opacity of these firms make it more difficult for banks to lend to them. Family control may even damage outside investors via tunneling, as documented for family controlled chaebols in Korea (Baek et al., 2006) or for typically familycontrolled business groups in India (Kali and Sarkar, 2011). More generally, the fact that family ownership gives more agency problems than stewardship benefits for external lenders and shareholders may depend on the degree of embeddedness by the controlling family (Peruzzi, 2017). So, it is believed that stewardship benefits tend to prevail in the initial phases when the founder controls the firm whereas the agency problems tend to prevail when, in later phases, the firm grows and later generations of the family become entrenched in the firm (Blanco-Mazagatos et al., 2007; Le Breton-Miller et al., 2011). For Italy, Bianco et al. (2012) argue that the greater sensitivity to uncertainty they find for family firms is basically due to these firms' greater opacity, ${ }^{2}$ and Miller et al. (2014) confirm that the agency costs of family ownership tend to outweigh the benefits of family stewardship with increasing embeddedness of the controlling family. Cucculelli and Peruzzi (2017), analyzing a sample of 1437 European family businesses, find that while external managers are asked to provide hard information, family firms' founders are more likely to be requested also for soft-information, additionally to hard information.

On the other hand, most relevant studies find no convincing evidence of a disadvantage for FBs' access to credit. For instance, Gugler et al. (2007) study the impact of firm ownership structure on investment cash flow sensitivity in Continental Europe and Anglo-Saxon countries. Their results show that asymmetric information and agency problems are more severe in Continental Europe, where investments are more dependent from internal funds availability, especially in the case of family controlled businesses. Also, Steijvers and Voordeckers (2009), on a cross sectional sample of lines-of-credit of the NSSBF database, find that family firms appear to be more likely to pledge personal collateral which suggests that agency costs of debt are higher in family firms. By contrast,

\footnotetext{
${ }^{1}$ However, Zellweger et al. (2007) argue that family firms provide transparent information to investors in the Swiss market.

${ }^{2}$ This notwithstanding the fact that Cascino et al. (2010) find that in Italy listed family firms convey financial information of higher quality compared to their non-family peers.
} 
Anderson and Reeb (2003), using a sample of 252 industrial firms from the S\&P 500, find evidence that family ownership is associated with lower agency cost of debt. And Pindado et al. (2011), using as a proxy for financing constraints the investment-cash flow sensitivity, show that European family listed companies are less financially constrained than non-family ones. These last results are consistent with the idea that family businesses enjoy lower agency costs and asymmetric information problems with external suppliers of finance.

Although bank loans are the principal form of external financing for family firms, there is very scarce evidence on their access to bank lending. Bopaiah (1998), using the Survey of Small Business Finance conducted in 1988-1989, investigates whether family ownership is associated with a greater credit availability. The results show that family businesses are significantly characterized by easier access to bank lending. Considering a different wave of the same survey, Steijvers et al. (2007), on the contrary, find that the higher agency costs and risk profile of family firms are translated in a higher degree of collateral protection required by banks.

Recently, two studies on Italy try to test family firms' credit availability before and during the latest financial crisis. Murro and Peruzzi (2017), using data on manufacturing firms from 1995 to 2006, display that family businesses are systematically associated with a higher probability of being credit rationed. D'Aurizio et al. (2015) study how the interaction between the family firm status and the screening technologies adopted by banks affected credit evolution during the 2007-2009 financial crisis. Looking at the growth rate of loan granted they find that banks that increased the role of soft information in their lending practices reallocated credit towards family businesses. This suggests that a full understanding of the issue of credit availability for family businesses should benefit from properly considering the type of lending technology employed by banks.

\subsection{The role of lending technologies}

Banks lend to SMEs by means of a variety of technologies. Berger and Udell (2006) define a lending technology as "a unique combination of primary information source, screening and underwriting policies/procedures, loan contract structure, and monitoring strategies/mechanisms". The literature has thus far focused on two classes: transaction-based lending technologies and relationship lending technologies (see, e.g., Berger and Udell, 2006, Bartoli et al., 2013a). These two lending technologies are normally distinguished by the information that the bank uses in granting and monitoring the loan. Transactional lending technologies are based primarily on hard information (quantitative information, such as that derived from balance sheets and/or collateral guarantees), while relationship lending technologies assigns a key role to soft information (qualitative information obtained via personal interaction). The literature suggests that large banks 
hold a comparative advantage in transactional lending, while the smaller or local banks have an edge in relationship lending (Stein, 2002). Moreover, the conventional view in the literature is that relationship lending is the obvious way to manage the opaqueness of SMEs (De la Torre at al., 2010, Ferri and Murro, 2015).

Several papers have analyzed the impact of relationship lending on the financing of the SMEs. Bartoli et al. (2011) find evidence that during the harshest phase of the 2008 Financial Crisis Italian banks tended to support borrowers characterized by more intense informational tightness. Cole (1998) finds that a lender is less likely to grant credit to a firm if the customer relationship has lasted for one year or less, or if the firm deals with other financial counterparts. Considering Belgian enterprises, Degryse and Van Cayseele (2000) identify the role of relationship banking along two different dimensions: borrowing rates increase with the length of the firm-bank relationship, while borrowing rates decrease when the scope of the firm-bank relationship - defined as the purchase of additional information intensive services (other than the loan) - increases.

In addition, both the theoretical and the empirical literatures have started to study also the transaction lending technologies. Berger and Udell (2006) suggest that transaction lending is not a single homogeneous lending technology but should be separated into a number of distinct transaction technologies used by financial institutions. ${ }^{3}$ Also the empirical literature tries to explain the transaction-based lending technologies (see, for example, Berger and Frame, 2007 and Ferri et al., 2017).

Finally, some recent studies (see, e.g., Beck et al. 2011; Berger and Udell, 2006) propose a new paradigm for bank SME finance, arguing that large banks can be as effective in SME lending through transactional lending technologies and centralized organizational structures instead of relationship lending. Bartoli et al. (2013a) show that the same firm tends to receive credit via different lending technologies. However, an additional finding shows that more soft information is produced when the bank uses relationship lending technology as the primary technology individually or coupled with transactional lending technologies. Thus, it appears that the way soft information becomes embodied in the lending decision might still differ between relational vs. transactional banks/technologies.

\section{Data and methodology}

\subsection{Empirical methodology and data description}

\footnotetext{
${ }^{3}$ Berger and Udell (2006) underline that transactions technologies include financial statement lending, small business credit scoring, asset-based lending, factoring, fixed-asset lending, and leasing. They define and describe each of these lending technologies, highlight its distinguishing features, and show how the technology addresses the opacity problem.
} 
We analyze the role of family ownership and lending technologies on credit rationing. To test our hypotheses we consider an empirical model of the probability that firms are credit rationed. Denote $y^{*}{ }_{1}$ the amount of credit the firm would wish to obtain and $y_{2}{ }_{2}$ the size of the loan actually granted by the bank, we have that the firm is rationed any time $y^{*}=\left(y^{*}{ }_{1}-y^{*}{ }_{2}\right)>0$. Thus, we can model the probability of rationing as:

$$
\begin{aligned}
& \mathrm{y}=1\left(\mathrm{y}^{*}>0\right) ; 0 \text { otherwise } \\
& \mathrm{y}^{*}=\mathrm{a}_{1} \mathrm{f}+\mathrm{b}_{1} \mathrm{x}+\mathrm{z}_{1} \mathrm{~d}_{11}+\mathrm{u}_{1}
\end{aligned}
$$

where $y$ is our measure of credit rationing (a dummy variable taking value one if the firm is rationed and zero otherwise); $f$ is our measure of family ownership; $x$ is a vector of the lending technologies used by the main bank, $z_{1}$ is a vector of control variables, and $u_{1}$ is the residual.

Our main data source is a survey carried out by Si.Camera-Unioncamere in 2015. The data refer to a representative sample of 2,500 firms of the agricultural, industrial and services sectors. The data collection was performed through a survey carried out by a professional Contractor, with the aim of gathering both qualitative and quantitative information at the firm level. The questionnaire submitted to the firms covers four different broad firm's areas: a) ownership and management structure; b) workforce characteristics (skills, type of contracts, training); c) investment, technological innovation, R\&D (and related financing); d) financial structure and bank-firm relationships.

Table 1 displays summary statistics, while Table A.1 provides a detailed description of all the variables employed in the empirical analysis. From a territorial point of view, almost half of the firms are located in the North of Italy (43\% of the total), the most developed area of Italy. About one third are located in the South (32\%), the least developed area, and $25 \%$ in the Center, the part of the country featuring intermediate economic development. The distribution among sectors shows that a large part of the firms belongs to the service sector (54\%): in particular, $19 \%$ in commerce, $15 \%$ in touristic activities and $20 \%$ in other services activities, $23 \%$ in manufacturing and $15 \%$ in construction. Only $8 \%$ of the surveyed firms belong to the agricultural sector. Reflecting a wellknown feature of Italian capitalism, small-sized enterprises (1-49 employees) are prevalent (87\%), while only $13 \%$ are medium and large enterprises. In fact, surveyed firms have 20 employees on average. Concerning the level of education, the average share of graduated employees is $11 \%$. Furthermore, by legal form, $44 \%$ of the firms are personally owned enterprises (ditte individuali), while $36 \%$ are public limited companies (società di capitali) and $20 \%$ are partnerships (società di persone). Another feature of Italy's productive sector is the presence of families in business 
activities. FBs represent more than 4/5 (82.9\%) and this phenomenon is relevant in all sectors of activities as well as in every territorial area. ${ }^{4}$ Regarding bank relationships, firms with relations with only one bank are about half of the sample (49\%), while $24 \%$ have relationships with two banks and another $24 \%$ with three or more banks.

Table 1 also reports the mean values separately for FBs and non-family businesses as well as a $t$-test for the differences between the two group means. Statistically significant differences are identified for firm size (FBs have fewer employees), degree of corporations (FBs are less likely corporations), share of graduate employees (FBs have fewer graduates), female firms (FBs are more likely female), regional GDP per capita (FBs belong to regions with lower average GDP per capita). Regarding relationships with banks, FBs are more likely to have only one bank or two banks whereas, conversely, they are less likely to have two or more banks and three or more banks.

\subsection{Credit rationing and lending technologies indices}

To define our indicators of credit rationing, we use the firms' answers to two questions of the survey (not necessarily related to the main bank). The first is question C3 (see the Appendix): "Considering the financial needs expressed by your company, credit extended by the bank was?". We construct a dummy variable taking value one if the firm answers "Not completely adequate" or "Inadequate". Moreover, we consider the firm to be rationed also if it answers question C2 (see the Appendix) with the tags 2, 3, 4 or $5 .^{5}$ In this way, we consider as rationed also discouraged firms. Table 1 shows that $10 \%$ of the firms are credit rationed. This percentage is almost the same among family and non-family firms. These data are in line with those obtained by other papers that analyze credit rationing. For example, using the EFIGE Survey, Ferri et al. (2017) find that in 2007-2009 about 4.4 percent of Italian firms suffered from rationing, and this figure increases to 12.6 percent when discouraged borrowers are included (see also Angori et al., 2017).

We capture the characteristics of the different lending technologies using question B4: "It could make a judgment on the ability of the bank to relate to your firm in relation to the following aspects" (see the Appendix). Our measure uses the weights (in descending order, high ability, medium, low, insufficient) a firm assigned to each listed characteristic/criterion. We then link the factors more closely associated with each lending technology. We focus on the two macro-classes of lending technologies from this classification: transactional lending and relationship lending (Berger and Udell, 2006). To consider the transactional technology we use the answer to the

\footnotetext{
${ }^{4}$ The above figures for family ownership are in the range of those obtained by studies on family ownership in Italy. For example, in Murro and Peruzzi (2017) almost 80 percent of firms are family owned.

${ }^{5}$ Is important to state that our measure is a self-reported measure of credit rationing, and not a direct measure of credit rationing. However, similar proxies have been widely used in the literature on credit rationing (see e.g., Jappelli, 1990; Angelini et al., 1998; Minetti and Zhu, 2011)
} 
criterion "explanation of the bank costs and conditions of services offered". We construct a dummy variable, which takes a value of one if the firm answers high/average ability. For relationship lending, we use the criterion "Consulting about investment opportunities" and construct a dummy variable, which takes a value of one if the firm answers high/average ability. ${ }^{6}$ These measures are in line with that used by previous papers that study lending technologies and their impact on credit availability (see, e.g., Bartoli et al., 2013a; Cosci et al., 2016; Cucculelli et al., 2018).

Table 1 shows also the summary statistics of the two lending technology indices. The lending factors related to the relationship lending technology are relatively more frequently emphasized; in fact, the mean of the index of relationship lending is 0.577 , while the mean for the transactional index is 0.391. These data, showing that relationship lending is the most widespread lending technology, are not surprising considering the average size of the firms in the sample. Finally, Table 1 displays that FBs are less likely to engage with a main bank using a transactional lending technology while they have a slightly higher propensity to interlock with a main bank using a relationship lending technology.

\subsection{Control variables}

Finally, we discuss the other control variables included in the regressions. To account for the fact that more productive and larger firms are less likely to be rationed, we include firm size (the log of total employees; e.g., Fagiolo and Luzzi, 2006). We also include a dummy variable indicating whether the firm is a corporation (Bartoli et al., 2014), the percentage of graduated employees in the firm, and a dummy variable if the firm is a female firm. ${ }^{7}$ Additionally, we control for the extent of information asymmetries a firm suffers. Following Cucculelli et al. (2018), two dummy variables are included to control for the varying degree of information asymmetries due to a firm's business activities. First, considering that export activities may amplify a firm's information asymmetries vis-à-vis its banking partner(s), we insert a dummy variable valued one for exporting firms (Murro, 2013; Minetti and Zhu, 2011). Second, for its banking partner(s) a firms' information asymmetry may increase if the firm engages in R\&D and innovation activities (Alessandrini et al., 2010; Minetti et al., 2015a; Mancusi and Vezzulli, 2014): a supplementary dummy variable is inserted to control for these cases. These two measures are also included as indirect proxies of firms'

\footnotetext{
${ }^{6}$ This definition of relationship lending is in line with Berger and Udell (2006) that suggest "under relationship lending, the financial institution relies primarily on soft information gathered through contact over time with the SME (...). This soft information may also include an assessment of the future prospects of the SME". (Berger and Udell, 2006 pag. 2951)

${ }^{7}$ Female firms refer to firms where the business ownership is female or the majority of shareholders or the capital correspond to women.
} 
profitability. Moreover, to control more directly for profitability, we add a dummy variable equal to one if the firms' sales increase in 2014 (the last balance sheet available), zero otherwise.

Regarding relevant external conditions, we consider whether the firm experienced a termination of a rapport with one or more banks. Building on the intuition that the termination of a firm-bank relationship may intensify asymmetric information and credit constraints (Bonaccorsi Di Patti and Gobbi, 2007), our specification features a dummy variable identifying situations where a firm-bank relationship was recently discontinued. Moreover, as a robustness check, in an untabulated regression we include also a dummy variable equal to one whether the firm was supported by a mutual guarantee institution (MGI). ${ }^{8}$ When an MGI provides external collateral to the firm this will make it easier for banks to lend to that firm (Comeig et al., 2014). In fact, the external collateral reduces the risk for the lending bank, and the signal that the firm has successfully passed the screening test by the MGI - which, in case the loan is granted, may also contribute monitoring the firm - attenuates the information asymmetry. ${ }^{9}$

In addition, we include industry dummy variables to account for sectoral differences in financial needs and in the probability of credit rationing (Mc Namara et al., 2017). Finally, we control for the area in which the firm is located and its level of economic development. In fact, the three Italian macro-regions differ significantly in terms of socio-economic development (D'Onofrio et al., 2017). In particular, we include two area fixed effects (Center and South) and GDP per capita in the region in 2014.

\section{Results}

\subsection{Baseline estimates}

In this section, we investigate the impact of family ownership and lending technologies on the probability that a firm is credit rationed. We try to answer two main questions. Are banks less willing to lend to FBs? Are lending technologies and/or extent of multiple banking relevant to understand family firms' credit availability? Following the literature above, we have no clear hypothesis for the first question. By contrast, following D'Aurizio et al. (2015), we expect that a FB in relation with a main bank that prefers using transactional lending technology is more likely credit rationed. Moreover, we expect that a tighter relationship with the main bank reduces the probability of credit rationing.

\footnotetext{
${ }^{8}$ Results, available upon request, are qualitatively similar.

${ }^{9}$ It is worth noting that Bartoli et al. (2013b) find that an MGI's support significantly lowered the probability of Italian small businesses suffering financial tension at the peak of the 2007-2009 financial crisis and that MGIs played a signaling role beyond the simple provision of collateral.
} 
Table 2 reports the baseline estimations. In particular, in column 1 we show the regressions in which we only consider the impact of family ownership on credit rationing. Instead, in columns 2-4 we study also the effect of relational and transactional lending technologies on credit rationing. In column 2, we insert relationship lending and the interaction between this technology and family ownership; in column 3, we include transactional lending and the interaction with the family variable. In column 4, we insert both technologies with their interactions with family ownership.

The findings in column 1 show that family ownership has a positive but insignificant impact on credit rationing. The results are different when we consider also lending technologies. The findings in columns 2 and 3 show that both coefficients for relational and transactional technologies are significant and negative. The coefficient of relationship lending is significant at the $1 \%$ level and suggests that when the bank uses relationship lending the firms are $12.6 \%$ less likely to be rationed. Moreover, the coefficient for transactional lending is significant at the 5\% level, and the marginal effect is equal to -0.078. Finally, the results in column 4 suggest that lending technologies are not equally beneficial for FBs. In fact, the interaction between transactional lending and family ownership is significant and positive. This result suggests that a family firm is more likely rationed when it interacts with a main bank that uses the transactional business model. This is consistent with findings in the literature that underline the role of lending technologies for FBs (Cucculelli et al., 2018; Murro and Peruzzi, 2017).

As for the control variables, in line with the theoretical predictions the results show that a recent discontinuity in the relationship with the main bank and innovation activities statistically increase the probability of rationing. By contrast, firms with more graduated employees are marginally less likely to be rationed, such as the firms located in regions with higher GDP or in the Center of Italy. The coefficients on size, corporation, female firms and export are not statistically significant.

Returning to the specific issue of FBs, it is important to ascertain whether the higher agency cost of debt hypothesis (Steijvers et al., 2007; Steijvers and Voordeckers, 2009) receives empirical support. In Table 1, the t-test suggests that family firms are only marginally asked to pledge more collateral. In column 5 of Table 2, we test this theory by interacting the dummy for whether the bank asked the firm to increase its collateral guarantees with the FB dummy. The results show that, while the request of new guarantees increases the probability of credit rationing, the interaction with FB dummy is significant and negative.

There is a risk that our findings about FBs are not really about the FBs' characteristics but instead due to sample composition. For this reason, as a robustness check, in Table 3, we run our baseline 
estimations using a propensity score matching to balance the sample. ${ }^{10}$ The results are robust also in this specification. In particular, relationship lending appears to reduce the probability of credit rationing, while transactional lending seems to be detrimental for family firms (the interaction term is positive and significant in both the specifications in columns 3 and 4). Finally, FBs asked for more guarantees are less likely to be rationed (column 5).

\section{$4.2 \quad$ Non-linear effects}

In Table 4, we try to disentangle whether there are some non-linarites in the relationship among family ownership, lending technologies and credit rationing. In particular, we study the role of firms' size (Panel A), age (Panel B) and geographical area (Panel C). We first split the sample based on a firm's number of employees. In columns 1-4 of Panel A, we show the results for firms with fewer than 10 employees. In columns 5-8, we report the findings for the other firms. This sample split suggests that our results are affected by firms' size. In particular, relationship banking seems to be particularly helpful for family micro firms (columns 2 and 4), while the findings confirm the beneficial effect of relationship lending for all the firms with more than 10 employees (columns 6 and 8). Moreover, small and medium FBs seem to be more credit rationed (column 5).

In Panel B, we split the sample according to the age of the firm. In particular, in columns 1-4 we consider the firms with less than 20 years (the median value of the sample), in columns 5-8 the firms with more than 20 years. The findings reveal that, while the relationship lending is beneficial for all the firms, transactional lending technologies are particularly negative for older family firms. This result is in line with the Le Breton-Miller et al. (2011) and Miller et al. (2014) hypothesis that family control increases agency cost of debt only when the family becomes entrenched with second generation managers and heirs taking the stage.

In Panel $\mathrm{C}$, we report the results when we split the sample according to the geographical area in which the firm is located. The findings show that transactional lending has a negative effect for firms in Central and Southern regions, while relationship lending is beneficial for all the firms. In the Center the likelihood of credit rationing is found to increase with firm size - contrary to expectations (e.g., Fagiolo and Luzzi, 2006) - and to be higher for family firms. By contrast, family ownership reduces the probability of rationing for firms in the South. These findings are in line with the literature suggesting that family firms could have a role in reducing the agency cost of debt in local markets with low levels of social capital and trust (Stacchini and Degasperi, 2015; Murro and

\footnotetext{
${ }^{10}$ Through this method, we estimate the probability of credit rationing of a sample of matched firms, that is, family and non-family businesses sharing similar characteristics. Matched firms are selected in two alternative ways: (i) without replacement using all matching firms within the predefined propensity score distance (caliper) $\delta=0.0001$ and (ii) using the control firm with the closest propensity score (nearest neighbour), without resampling or distance restrictions. Table 3 reports the findings obtained following the second approach. The results of the first approach, available upon request, are qualitatively similar.
} 
Peruzzi, 2017). Moreover, these results are consistent with the idea that the role of lending technologies could differ among geographical areas (see, e.g., Ferri and Messori, 2000).

\subsection{The role of multiple banking}

Multiple credit relationships can dilute the tightness of a firm's relationship with its main bank, thus exacerbating informational asymmetries and the probability of credit rationing (Petersen and Rajan, 1994). Moreover, the fragmentation of credit relationships is often found to be an obstacle to credit access for Italian firms (see, e.g., Accetturo et al., 2013; Minetti et al., 2017). The survey asks each firm to indicate the number of banks from which it borrowed. Nearly $49 \%$ of the firms have one bank, the mean number of banks is 2.2 and the median is 2 . In Table 5, we try to study the impact of the tightness of the relationship with the main bank, considering the role of multiple banking. In line with the literature, we expect that FBs with only one or two banks are less likely rationed. In Table 5, we interact the family variable with four indicators that measure the number of banks from which the firm borrowed. The results in columns 1 and 3 are in line with the hypotheses in the literature. In particular, the interaction between family and the dummy variable equal to one if the firm interacts with only one bank (column 1) is negative and statistically significant. Column 3 reports the interaction between family and the dummy equal to one if the firm operates with one or two banks. The results are similar. Columns 2 and 4 of Table 5 report the opposite effect. Family firms that operate with more banks are more likely to be rationed.

\section{Conclusions}

In this paper, we studied the extent and the determinants of credit rationing, as self-reported by firms, in a survey of small-sized enterprises active in Italy in 2015. Specifically, we focused on the nexus between family ownership and the intensity of relationship banking, where the latter is measured by the set up of banking relationships, and by the type of lending technology adopted by a firm's main bank. The relevance of our research question stems from two considerations. First, family businesses are the backbone of Italy's productive system totaling more than $70 \%$ of employees in the industry and services sectors. Second, because of the stress due to the prolonged macroeconomic crisis and stagnation, Italy's banking system has intensified credit rationing and this might have affected more intensely the opaque firms, such as FBs.

Our analyses delivered nuanced results. On one hand, the data gathered suggest that in 2015 the phenomenon of credit rationing affected a sizeable $10 \%$ of the surveyed enterprises. At the same time, we found no evidence that rationing was systematically larger for FBs. Credit rationing is lower for firms (and for family owned micro firms) whose main bank adopts a relationship lending 
technology, while it may be higher at the FBs whose main bank employs a transactional lending technology. Moreover, closer inspection showed that family ownership does produce intensified credit rationing when the extent of relationship banking is weakened, e.g. when the set up of banking relationships and/or the lending technology adopted by a firm's main bank turn out inappropriate. Accordingly, for the FBs concentrating their banking relationships in one bank (two banks) credit rationing is significantly lower whereas it is significantly higher at FBs diluting their relationships across two or more (three or more) banks.

Overall, our empirical analyses suggest that a higher propensity to relationship banking appears essential to smooth out credit flows to family owned enterprises. Namely, the adoption of relationship lending technologies - identifying the propensity to relationship banking by a firm's main bank - and the concentration of a firm's relationships in at most two banks - pinpointing a firm's propensity to engage in relationship banking - are key ingredients to spare heightened credit rationing for family owned enterprises. Nonetheless, it takes two to tango. While the demand for relationship banking by enterprises is under their own control, the supply of relationship banking by the banks rests with the banks. And the news on the latter is somewhat uncomfortable.

In fact, given that more and more banks are moving from relationship to transactional lending technologies in order to cut their costs, ${ }^{11}$ and also following regulatory incentives. It is, in fact, worth stressing that the European Union has adopted a one-size-fits-all approach, which any bank must comply to irrespective of its mission and ownership structure (Masera, 2011, 2012; Ferri and Neuberger, 2014). While on the contrary the US has kept its tiered approach with three separate tiers in which commercial banks, community banks and credit unions follow different rules. ${ }^{12}$ From this perspective, it has been claimed that US regulation may favor small business (and family business) lending. For example, De Young et al. (2012) argue and provide evidence that community banks and credit unions, with local roots/personal knowledge of borrowers make better judgements on the creditworthiness of small firms and households, thereby reducing credit rationing and information failures. To the opposite, in the one-size-fits-all regulatory environment of the EU, our results suggest that FBs may be at risk of intensified credit rationing in the future. Should that scenario materialize, it would have strong policy implications. Indeed, some policy interventions like the deployment of public guarantees for lending to small businesses and FBs might then be desirable to prevent suffocating family businesses and their contribution to economic recovery.

\footnotetext{
${ }^{11}$ For instance, Del Prete et al. (2013) document that in the period 2006-2009 the use of rating methodologies and scoring spread even to smaller banks in Italy. They also find that the trend towards decentralization of decisions stopped and the average stay of branch managers declined.

${ }^{12}$ On the rationale of tailored bank regulation, see e.g. Tarullo (2015) who argues that the semifixed nature of ever increasing compliance costs places distortionary burdens on small banks (which do not have a systemic impact on financial stability). Hence the need for tiered bank surveillance.
} 
About the future research, using the new waves of the survey, we will study whether estimated coefficients are stable over time and if the novelty in the banking regulation (e.g., Italian authorities actively promoted bank concentration among banche popolari and banche cooperative) had a disproportionate impact on lending by small banks to FBs. 


\section{References}

Accetturo, A., Bassanetti, A., Bugamelli, M., Faiella, I., Finaldi Russo, P., Franco, D., Omiccioli, M. (2013). Il sistema industriale italiano tra globalizzazione e crisi (The Italian industrial system between globalization and crisis). Bank of Italy Occasional Paper No. 193.

Alessandrini, P., Presbitero, A.F., Zazzaro, A. (2010). Bank size or distance: what hampers innovation adoption by SMEs?, Journal of Economic Geography 10(6): 845-881.

Anderson, R.C., Duru, A., Reeb, D.M. (2009). Founders, heirs, and corporate opacity in the United States, Journal of Financial economics 92(2): 205-222.

Anderson, R.C., Reeb, D.M. (2003). Founding family ownership and the agency cost of debt, Journal of Financial Economics 68: 263-285.

Angelini, P., Di Salvo, R., Ferri, G. (1998). Availability and cost of credit for small businesses: customer relationships and credit cooperatives, Journal of Banking \& Finance 22(6-8): 925954.

Angori, G., Aristei, D., Gallo, M. (2017). Lending technologies, banking relationships, and firms' access to credit in Italy: the role of firm size, mimeo.

Astrachan, J.H., Carey Shanker, M. (2003). Family Businesses' Contribution to the U.S. Economy: A Closer Look, Family Business Review 16: 211-219.

Baek, J.-S., Kang, J.-K., Lee, I. (2006). Business groups and tunneling: Evidence from private securities offerings by Korean chaebols, The Journal of Finance 61(5): 2415-2449.

Bartoli, F., Ferri, G., Murro, P., Rotondi, Z. (2011). Soft Information and Loan Supply in the Crisis: Evidence from the Credit Files of a Large Bank, Rivista Bancaria 5-2011: 7-28.

Bartoli, F., Ferri, G., Murro, P., Rotondi, Z. (2013a). SME financing and the choice of lending technology in Italy: Complementarity or substitutability?, Journal of Banking \& Finance 37: 5476-5485.

Bartoli, F., Ferri, G., Murro, P., Rotondi, Z. (2013b). Bank-firm relations and the role of Mutual Guarantee Institutions at the peak of the crisis, Journal of Financial Stability 9(1): 90-104.

Bartoli, F., Ferri, G., Murro, P., Rotondi, Z. (2014). Bank support and export: evidence from small Italian firms, Small Business Economics 42(2), 245-264.

Beck, T., Demirgüç-Kunt, A., Martinez Peria, M.S. (2011). Bank Financing for SMEs: Evidence Across Countries and Bank Ownership Types, Journal of Financial Services Research 39: 3554.

Berger, A.N., Frame W.S. (2007). Small business credit scoring and credit availability, Journal of Small Business Management 46: 5-22.

Berger, A.N., Udell, G.F. (2006). A more complete conceptual framework for SME finance, Journal of Banking \& Finance 30: 2945-2968.

Bianchi, M., Bianco, M., 2008. L'evoluzione della corporate governance in Italia: Meno piramidi più coalizioni? Il Mulino, Bologna.

Bianco, M., Bontempi, M.E., Golinelli, R., Parigi, G. (2013). Family firms' investments, uncertainty and opacity, Small Business Economics 40(4): 1035-1058.

Blanco-Mazagatos, V., De Quevedo-Puente, E., Castrillo, L.A. (2007). The Trade-Off Between Financial Resources and Agency Costs in the Family Business: An Exploratory Study, Family Business Review 20(3): 199-213. 
Bonaccorsi Di Patti, E., Gobbi, G. (2007). Winners or losers? The effects of banking consolidation on corporate borrowers, The Journal of Finance 62(2): 669-695.

Bopaiah, C. (1998). Availability of Credit to Family Business, Small Business Economics 11: 7586.

Cascino, S., Pugliese, A., Mussolino, D., Sansone, C. (2010). The Influence of Family Ownership on the Quality of Accounting Information, Family Business Review 23(3): 246-265.

Cole, R.A. (1998). The importance of relationship to the availability of credit, Journal of Banking \& Finance 22: 959-977.

Cosci, S., Meliciani, V., Sabato, V. (2016). Relationship lending and innovation: empirical evidence on a sample of European firms, Economics of Innovation and New Technology 25(4): 335357.

Cucculelli, M., Peruzzi, V. (2017). Bank screening technologies and the founder effect: Evidence from European lending relationships, Finance Research Letters, 20, 229-237.

Cucculelli, M., Peruzzi, V., Zazzaro, A. (2018). Relational capital in lending relationships: Evidence from European family firms, Small Business Economics, forthcoming.

Comeig, I., Del Brio, E.B., Fernandez-Blanco M.O. (2014). Financing successful small business projects, Management Decision 52(2): 365-377.

D’Aurizio, L., Oliviero, T., Romano, L. (2014). Family firms' strategies and performance in the crisis years, Review of Economic Conditions in Italy 1: 79-99.

D’Aurizio, L., Oliviero, T., Romano, L. (2015). Family firms, soft information and bank lending in a financial crisis, Journal of Corporate Finance 33: 279-292.

D’Onofrio, A., Minetti, R., Murro, P. (2017). Banking development, socioeconomic structure and income inequality, Journal of Economic Behavior \& Organization, forthcoming.

Degryse, H., Van Cayseele, P. (2000), Relationship lending within a bank-based system: Evidence from European small business data, Journal of Financial Intermediation 9: 90-109.

De la Torre, A., Martinez Peria, M.S., Schmukler, S.L. (2010). Bank involvement with SMEs: Beyond relationship lending, Journal of Banking \& Finance 34: 2280-2293.

Del Prete, S., Pagnini, M., Rossi, P., Vacca, V. (2013). Organizzarsi per prestare in tempo di crisi. Risultati di un'indagine sulle banche. Bank of Italy Occasional Paper No. 154, April.

DeYoung, R., Glennon, D., Nigro, P., Spong, K. (2012). Small Business Lending and Social Capital: Are Rural Relationships Different?" University of Kansas Center for Banking Excellence Research paper, No. 1-2012.

Duarte, F., Matias Gama, A.P., Esperança, J.P. (2016). The Role of Collateral in the Credit Acquisition Process: Evidence from SME Lending, Journal of Business Finance \& Accounting 43(5-6): 693-728.

Engel, D., Stiebale, J. (2014). Private equity, investment and financial constraints: firm-level evidence for France and the United Kingdom, Small Business Economics 43(1): 197-212.

Fagiolo, G., Luzzi, A. (2006). Do liquidity constraints matter in explaining firm size and growth? Some evidence from the Italian manufacturing industry, Industrial \& Corporate Change 15(1): 1-39.

Ferri, G., Messori, M. (2000). Bank-firm relationships and allocative efficiency in Northeastern and Central Italy and in the South, Journal of Banking \& Finance 24: 1067-1095. 
Ferri, G., Murro, P. (2015). Do firm-bank 'odd couples' exacerbate credit rationing?, Journal of Financial Intermediation 24: 231-251.

Ferri, G., Murro, P., Peruzzi, V., Rotondi, Z. (2017). Bank lending technologies and credit availability in Europe. What can we learn from the crisis?. No. 135. Money and Finance Research group (Mo. Fi. R.).

Ferri, G., Neuberger, D. (2014). The banking regulatory bubble and how to get out of it. Rivista di Economia Politica, April/June, Special issue 4-6: 39-69.

Ferri, G., Pini, M., Scaccabarozzi, S. (2014). Le imprese familiari nel tessuto produttivo italiano: caratteristiche, dimensioni, territorialità, Rivista di Economia e Statistica del Territorio 2: 4877.

Gugler, K., Mueller, D.C., Yurtoglu, B.B. (2007). Corporate governance and the determinants of investment, Journal of Institutional and Theoretical Economics 163: 598-626.

Hamelin, A. (2013). Influence of family ownership on small business growth. Evidence from French SMEs, Small Business Economics 41(3): 563-579.

Jappelli, T. (1990). Who is credit constrained in the US economy? Quarterly Journal of Economics 105: 219-234.

Kali, R., Sarkar J. (2011). Diversification and tunneling: Evidence from Indian business groups, Journal of Comparative Economics 39(3): 349-367.

Le Breton-Miller, I., Miller, D., Lester, R.H. (2011). Stewardship or agency? A social embeddedness reconciliation of conduct and performance in public family businesses, Organization Science 22(3): 704-721.

Mancusi, M.L., Vezzulli, A. (2014). R\&D and credit rationing in SMEs, Economic Inquiry 52(3): 1153-1172.

Mandl, I. (2008). Overview of Family Business Relevant Issues, Vienna: Austrian Institute for SME Research.

Masera, R. (2011). Taking the Moral Hazard out of Banking: The Next Fundamental Step in Financial Reform, PSL Quarterly Review 64: 105-142.

Masera, R. (2012). Gli standard di capitale di Basilea: soluzione o concausa dei problemi di instabilità? Testimony to the Finance Committee of Italy's Lower House, February $1^{\text {st }}$.

Mc Namara, A., Murro, P., O'Donohoe, S. (2017). Countries lending infrastructure and capital structure determination: The case of European SMEs, Journal of Corporate Finance 43: 122138.

Miller, D., Le Breton-Miller, I., Minichilli, A., Corbetta, G., Pittino, D. (2014). When do nonfamily CEOs outperform in family firms? Agency and behavioural agency perspectives, Journal of Management Studies 51(4): 547-572.

Minetti, R., Murro P., Paiella, M. (2015a). Ownership structure, governance, and innovation, European Economic Review 80: 165-193.

Minetti, R., Murro P., Rotondi, Z., Zhu, S.C. (2017). Financial Constraints, Firms' Supply Chains and Internationalization, Journal of the European Economic Association, forthcoming.

Minetti, R., Murro P., Zhu, S.C. (2015b). Family Firms, Corporate Governance and Export, Economica 82: 1177-1216.

Minetti, R., Zhu, S.C. (2011). Credit constraints and firm export: microeconomic evidence from Italy, Journal of International Economics 83(2): 109-125. 
Murro, P. (2013). The determinants of innovation: What is the role of risk?, The Manchester School 81(3), 293-323.

Murro, P., Peruzzi, V. (2017). Family firms and access to credit. Is family ownership beneficial? CERBE Working papers 23.

Peruzzi, V. (2017). Does family ownership structure affect investment-cash flow sensitivity? Evidence from Italian SMEs, Applied Economics, 49(43): 4378-4393.

Petersen, M.A., Rajan, R.G. (1994). The benefits of lending relationships: Evidence from small business data, Journal of Finance 49(1): 3-37.

Pindado, J., Requejo, I., de la Torre, C. (2011). Family control and investment-cash flow sensitivity: Empirical evidence from the Euro zone, Journal of Corporate Finance 17: 13891409.

Schulze, W., Lubatkin, M., Dino, R. (2003). Exploring the agency consequences of ownership dispersion among the directors of private family firms, Academy of Management Journal 46(2): 179-194.

Stacchini, M., Degasperi, P. (2015). Trust, family businesses and financial intermediation, Journal of Corporate Finance 33, 293-316.

Steijvers, T., Voordeckers, W. (2009). Private Family Ownership and the Agency Costs of Debt, Family Business Review 22(4): 333-346.

Steijvers, T., Voordeckers, W., Vandemaele, S. (2007). The ownership-performance puzzle: agency issues in small and medium-sized family firms, mimeo.

Steijvers, T., Voordeckers, W., Vanhoof, K. (2010), Collateral, relationship lending and family firms, Small Business Economics 34(3): 243-259.

Stein, J.C. (2002). Information production and capital allocation: Decentralized vs. hierarchical firms, Journal of Finance 57: 1891-1921.

Tarullo, D. K. (2015). Tailoring Community Bank Regulation and Supervision: a speech at the Independent Community Bankers of America 2015 Washington Policy Summit, Washington, DC, April 30, 2015 (No. 846). Board of Governors of the Federal Reserve System (US).

Zellweger, T., Fueglistaller, U., Meister, R. (2007), The outperformance of family firms: the role of variance in earnings per share and analyst forecast dispersion on the Swiss market, Financial Markets and Portfolio Management 21(2): 203-220. 
Table 1. Summary statistics

\begin{tabular}{|c|c|c|c|c|c|}
\hline & \multicolumn{2}{|c|}{ All firms } & \multicolumn{3}{|c|}{ Ownership } \\
\hline & Mean & Std. Dev. & Family & Non-family & $t$-test \\
\hline Rationing & 0.101 & 0.301 & 0.101 & 0.100 & -0.031 \\
\hline Family & 0.829 & 0.377 & & & \\
\hline Transactional lending & 0.391 & 0.314 & 0.375 & 0.465 & 5.213 \\
\hline Relationship lending & 0.577 & 0.366 & 0.582 & 0.550 & -1.678 \\
\hline Only one bank & 0.486 & 0.500 & 0.525 & 0.297 & -9.256 \\
\hline Two banks & 0.236 & 0.425 & 0.234 & 0.245 & 0.501 \\
\hline Two or more banks & 0.480 & 0.500 & 0.437 & 0.687 & 10.048 \\
\hline Three or more banks & 0.243 & 0.429 & 0.202 & 0.441 & 9.347 \\
\hline Employees & 20.369 & 63.284 & 13.953 & 51.406 & 8.157 \\
\hline Corporation & 0.362 & 0.481 & 0.307 & 0.629 & 12.672 \\
\hline Graduated & 0.107 & 0.232 & 0.099 & 0.143 & 3.222 \\
\hline Female Firm & 0.170 & 0.375 & 0.180 & 0.118 & -3.502 \\
\hline Bank-firm discontinuity & 0.114 & 0.317 & 0.101 & 0.172 & 3.627 \\
\hline Innovation & 0.286 & 0.452 & 0.270 & 0.364 & 3.745 \\
\hline Export & 0.123 & 0.329 & 0.104 & 0.219 & 5.456 \\
\hline Growth in sales & 0.155 & 0.363 & 0.140 & 0.229 & 4.695 \\
\hline Increase guarantees & 0.104 & 0.305 & 0.107 & 0.091 & -0.763 \\
\hline Agriculture & 0.083 & 0.276 & 0.087 & 0.065 & -1.631 \\
\hline Manufacturing & 0.228 & 0.419 & 0.224 & 0.248 & 1.089 \\
\hline Construction & 0.149 & 0.356 & 0.152 & 0.132 & -1.091 \\
\hline Commerce & 0.191 & 0.393 & 0.195 & 0.172 & -1.143 \\
\hline Tourism & 0.149 & 0.356 & 0.155 & 0.121 & -1.948 \\
\hline Regional GDP 2014 & $26,703.84$ & $6,408.41$ & $26,509.02$ & $27,646.29$ & 3.428 \\
\hline North & 0.430 & 0.495 & 0.414 & 0.508 & 3.567 \\
\hline Center & 0.251 & 0.434 & 0.253 & 0.241 & -0.504 \\
\hline South & 0.319 & 0.466 & 0.333 & 0.251 & -3.550 \\
\hline
\end{tabular}

Note: This table reports summary statistics of the variables used in the empirical analysis. Family is a binary variable that equals one if the main shareholder is an individual or a family, zero otherwise. 
Table 2. Baseline estimations

\begin{tabular}{|c|c|c|c|c|c|}
\hline VARIABLES & $\begin{array}{c}(1) \\
\text { RATIONING } \\
\end{array}$ & $\begin{array}{c}(2) \\
\text { RATIONING } \\
\end{array}$ & $\begin{array}{c}(3) \\
\text { RATIONING } \\
\end{array}$ & $\begin{array}{c}(4) \\
\text { RATIONING } \\
\end{array}$ & $\begin{array}{c}(5) \\
\text { RATIONING } \\
\end{array}$ \\
\hline Family & $\begin{array}{c}0.003 \\
(0.018)\end{array}$ & $\begin{array}{c}0.007 \\
(0.024)\end{array}$ & $\begin{array}{l}-0.025 \\
(0.028)\end{array}$ & $\begin{array}{c}-0.022 \\
(0.032)\end{array}$ & $\begin{array}{c}0.032 \\
(0.031)\end{array}$ \\
\hline Family * Relationship lending & & $\begin{array}{l}-0.016 \\
(0.039)\end{array}$ & & $\begin{array}{c}-0.012 \\
(0.040)\end{array}$ & \\
\hline Relationship Lending & & $\begin{array}{c}-0.126 * * * \\
(0.034)\end{array}$ & & $\begin{array}{c}-0.129 * * * \\
(0.035)\end{array}$ & \\
\hline Family* Transactional lending & & & $\begin{array}{c}0.059 \\
(0.039)\end{array}$ & $\begin{array}{l}0.058^{*} \\
(0.033)\end{array}$ & \\
\hline Transactional lending & & & $\begin{array}{c}-0.078 * * \\
(0.036)\end{array}$ & $\begin{array}{c}-0.067 * * \\
(0.032)\end{array}$ & \\
\hline Family * Increase guarantees & & & & & $\begin{array}{c}-0.099 * * * \\
(0.035)\end{array}$ \\
\hline Increase guarantees & & & & & $\begin{array}{c}0.417 * * * \\
(0.099)\end{array}$ \\
\hline Size (ln employees) & $\begin{array}{c}0.004 \\
(0.005)\end{array}$ & $\begin{array}{l}-0.000 \\
(0.005)\end{array}$ & $\begin{array}{c}0.006 \\
(0.005)\end{array}$ & $\begin{array}{c}0.001 \\
(0.005)\end{array}$ & $\begin{array}{l}-0.004 \\
(0.006)\end{array}$ \\
\hline Corporation & $\begin{array}{c}0.006 \\
(0.019)\end{array}$ & $\begin{array}{c}-0.002 \\
(0.017)\end{array}$ & $\begin{array}{c}0.006 \\
(0.019)\end{array}$ & $\begin{array}{c}-0.002 \\
(0.017)\end{array}$ & $\begin{array}{l}-0.009 \\
(0.022)\end{array}$ \\
\hline Graduated & $\begin{array}{l}-0.045 \\
(0.028)\end{array}$ & $\begin{array}{c}-0.032 \\
(0.028)\end{array}$ & $\begin{array}{l}-0.047 \\
(0.029)\end{array}$ & $\begin{array}{l}-0.034 \\
(0.028)\end{array}$ & $\begin{array}{c}-0.039 \\
(0.049)\end{array}$ \\
\hline Female firm & $\begin{array}{c}-0.004 \\
(0.020)\end{array}$ & $\begin{array}{c}0.001 \\
(0.021)\end{array}$ & $\begin{array}{l}-0.003 \\
(0.021)\end{array}$ & $\begin{array}{c}0.002 \\
(0.021)\end{array}$ & $\begin{array}{c}0.000 \\
(0.035)\end{array}$ \\
\hline Bank-firm discontinuity & $\begin{array}{c}0.063 * * * \\
(0.019)\end{array}$ & $\begin{array}{c}0.034 * * \\
(0.017)\end{array}$ & $\begin{array}{c}0.066^{* * * *} \\
(0.019)\end{array}$ & $\begin{array}{c}0.036 * * \\
(0.017)\end{array}$ & $\begin{array}{l}0.049 * \\
(0.028)\end{array}$ \\
\hline Innovation & $\begin{array}{l}0.028^{*} \\
(0.014)\end{array}$ & $\begin{array}{c}0.026 * * \\
(0.013)\end{array}$ & $\begin{array}{c}0.029 * * \\
(0.015)\end{array}$ & $\begin{array}{c}0.027 * * \\
(0.013)\end{array}$ & $\begin{array}{c}0.032 \\
(0.023)\end{array}$ \\
\hline Export & $\begin{array}{c}-0.018 \\
(0.015)\end{array}$ & $\begin{array}{c}-0.014 \\
(0.015)\end{array}$ & $\begin{array}{l}-0.017 \\
(0.015)\end{array}$ & $\begin{array}{c}-0.014 \\
(0.016)\end{array}$ & $\begin{array}{c}-0.029 \\
(0.025)\end{array}$ \\
\hline Growth in sales & $\begin{array}{l}-0.021 \\
(0.017)\end{array}$ & $\begin{array}{c}-0.020 \\
(0.018)\end{array}$ & $\begin{array}{l}-0.020 \\
(0.017)\end{array}$ & $\begin{array}{l}-0.019 \\
(0.017)\end{array}$ & $\begin{array}{l}-0.025 \\
(0.031)\end{array}$ \\
\hline Regional GDP (2014) & $\begin{array}{c}-0.000 * * \\
(0.000)\end{array}$ & $\begin{array}{c}-0.000 * * \\
(0.000)\end{array}$ & $\begin{array}{c}-0.000^{*} \\
(0.000)\end{array}$ & $\begin{array}{c}-0.000 * * \\
(0.000)\end{array}$ & $\begin{array}{c}-0.000 * \\
(0.000)\end{array}$ \\
\hline Center & $\begin{array}{l}-0.020^{*} \\
(0.012)\end{array}$ & $\begin{array}{c}-0.023 * * \\
(0.010)\end{array}$ & $\begin{array}{l}-0.019 \\
(0.012)\end{array}$ & $\begin{array}{c}-0.022 * * \\
(0.010)\end{array}$ & $\begin{array}{l}-0.019 \\
(0.024)\end{array}$ \\
\hline South & $\begin{array}{l}-0.035 \\
(0.027)\end{array}$ & $\begin{array}{l}-0.036 \\
(0.023)\end{array}$ & $\begin{array}{l}-0.033 \\
(0.026)\end{array}$ & $\begin{array}{l}-0.034 \\
(0.023)\end{array}$ & $\begin{array}{l}-0.060 \\
(0.049)\end{array}$ \\
\hline Sector dummies & $\mathrm{Y}$ & $\mathrm{Y}$ & $\mathrm{Y}$ & $\mathrm{Y}$ & $\mathrm{Y}$ \\
\hline $\begin{array}{l}\text { Observations } \\
\text { Pseudo R-squared }\end{array}$ & $\begin{array}{l}2,146 \\
0.040\end{array}$ & $\begin{array}{l}2,146 \\
0.089\end{array}$ & $\begin{array}{l}2,146 \\
0.042\end{array}$ & $\begin{array}{l}2,146 \\
0.090\end{array}$ & $\begin{array}{l}1,081 \\
0.080\end{array}$ \\
\hline
\end{tabular}

Note: The table reports regressions marginal effects. The dependent variable is reported at the top of each column. The regressions are estimated by Probit. Robust standard errors are reported below coefficients. $(*)$ : coefficient significant at $10 \%$ confidence level; $(* *)$ : coefficient significant at $5 \%$ confidence level; $(* * *)$ : coefficient significant at less than $1 \%$ confidence level. 
Table 3. Baseline estimations using propensity score matching

\begin{tabular}{|c|c|c|c|c|c|}
\hline VARIABLES & $\begin{array}{c}(1) \\
\text { RATIONING } \\
\end{array}$ & $\begin{array}{c}(2) \\
\text { RATIONING } \\
\end{array}$ & $\begin{array}{c}(3) \\
\text { RATIONING } \\
\end{array}$ & $\begin{array}{c}(4) \\
\text { RATIONING } \\
\end{array}$ & $\begin{array}{c}(5) \\
\text { RATIONING } \\
\end{array}$ \\
\hline Family & $\begin{array}{c}0.008 \\
(0.018)\end{array}$ & $\begin{array}{l}-0.009 \\
(0.036)\end{array}$ & $\begin{array}{c}-0.057 * * \\
(0.028)\end{array}$ & $\begin{array}{l}-0.070^{*} \\
(0.039)\end{array}$ & $\begin{array}{c}0.036 \\
(0.036)\end{array}$ \\
\hline Family $*$ Relationship lending & & $\begin{array}{c}0.035 \\
(0.066)\end{array}$ & & $\begin{array}{c}0.041 \\
(0.066)\end{array}$ & \\
\hline Relationship Lending & & $\begin{array}{c}-0.134 * * * \\
(0.031)\end{array}$ & & $\begin{array}{c}-0.135 * * * \\
(0.032)\end{array}$ & \\
\hline Family* Transactional lending & & & $\begin{array}{l}0.129 * * \\
(0.051)\end{array}$ & $\begin{array}{c}0.115^{* *} \\
(0.045)\end{array}$ & \\
\hline Transactional lending & & & $\begin{array}{c}-0.074 * * \\
(0.035)\end{array}$ & $\begin{array}{c}-0.065 * * \\
(0.030)\end{array}$ & \\
\hline Family $*$ Increase guarantees & & & & & $\begin{array}{c}-0.084 * * \\
(0.034)\end{array}$ \\
\hline Increase guarantees & & & & & $\begin{array}{c}0.382 * * * \\
(0.101)\end{array}$ \\
\hline Size (ln employees) & $\begin{array}{l}-0.004 \\
(0.006)\end{array}$ & $\begin{array}{l}-0.008 \\
(0.006)\end{array}$ & $\begin{array}{l}-0.002 \\
(0.006)\end{array}$ & $\begin{array}{l}-0.006 \\
(0.007)\end{array}$ & $\begin{array}{l}-0.008 \\
(0.010)\end{array}$ \\
\hline Corporation & $\begin{array}{c}0.003 \\
(0.023)\end{array}$ & $\begin{array}{c}0.003 \\
(0.020)\end{array}$ & $\begin{array}{c}0.009 \\
(0.024)\end{array}$ & $\begin{array}{c}0.008 \\
(0.020)\end{array}$ & $\begin{array}{l}-0.051 \\
(0.044)\end{array}$ \\
\hline Graduated & $\begin{array}{c}-0.068 * * \\
(0.027)\end{array}$ & $\begin{array}{l}-0.055^{*} \\
(0.028)\end{array}$ & $\begin{array}{l}-0.071 * * \\
(0.028)\end{array}$ & $\begin{array}{c}-0.059 * * \\
(0.029)\end{array}$ & $\begin{array}{l}-0.043 \\
(0.057)\end{array}$ \\
\hline Female firm & $\begin{array}{l}-0.009 \\
(0.024)\end{array}$ & $\begin{array}{l}-0.005 \\
(0.021)\end{array}$ & $\begin{array}{l}-0.008 \\
(0.023)\end{array}$ & $\begin{array}{l}-0.004 \\
(0.020)\end{array}$ & $\begin{array}{c}0.015 \\
(0.060)\end{array}$ \\
\hline Bank-firm discontinuity & $\begin{array}{c}0.097 * * * \\
(0.029)\end{array}$ & $\begin{array}{c}0.064 * * * \\
(0.024)\end{array}$ & $\begin{array}{c}0.096 * * * \\
(0.030)\end{array}$ & $\begin{array}{c}0.064 * * * \\
(0.025)\end{array}$ & $\begin{array}{c}0.076 * * * \\
(0.026)\end{array}$ \\
\hline Innovation & $\begin{array}{c}0.021 \\
(0.018)\end{array}$ & $\begin{array}{c}0.017 \\
(0.020)\end{array}$ & $\begin{array}{c}0.026 \\
(0.017)\end{array}$ & $\begin{array}{c}0.022 \\
(0.018)\end{array}$ & $\begin{array}{c}0.010 \\
(0.022)\end{array}$ \\
\hline Export & $\begin{array}{l}-0.013 \\
(0.036)\end{array}$ & $\begin{array}{l}-0.008 \\
(0.036)\end{array}$ & $\begin{array}{l}-0.018 \\
(0.035)\end{array}$ & $\begin{array}{l}-0.013 \\
(0.036)\end{array}$ & $\begin{array}{c}0.014 \\
(0.056)\end{array}$ \\
\hline Growth in sales & $\begin{array}{l}-0.009 \\
(0.021)\end{array}$ & $\begin{array}{l}-0.009 \\
(0.020)\end{array}$ & $\begin{array}{l}-0.009 \\
(0.020)\end{array}$ & $\begin{array}{l}-0.010 \\
(0.019)\end{array}$ & $\begin{array}{l}-0.015 \\
(0.039)\end{array}$ \\
\hline Regional GDP (2014) & $\begin{array}{l}-0.000 \\
(0.000)\end{array}$ & $\begin{array}{l}-0.000 \\
(0.000)\end{array}$ & $\begin{array}{l}-0.000 \\
(0.000)\end{array}$ & $\begin{array}{l}-0.000 \\
(0.000)\end{array}$ & $\begin{array}{c}0.000 \\
(0.000)\end{array}$ \\
\hline Center & $\begin{array}{l}-0.020 \\
(0.025)\end{array}$ & $\begin{array}{l}-0.022 \\
(0.023)\end{array}$ & $\begin{array}{l}-0.017 \\
(0.026)\end{array}$ & $\begin{array}{l}-0.019 \\
(0.024)\end{array}$ & $\begin{array}{l}-0.005 \\
(0.029)\end{array}$ \\
\hline South & $\begin{array}{c}0.022 \\
(0.062)\end{array}$ & $\begin{array}{c}0.022 \\
(0.055)\end{array}$ & $\begin{array}{c}0.023 \\
(0.065)\end{array}$ & $\begin{array}{c}0.024 \\
(0.059)\end{array}$ & $\begin{array}{c}0.129 \\
(0.078)\end{array}$ \\
\hline Sector dummies & $\mathrm{Y}$ & $\mathrm{Y}$ & $\mathrm{Y}$ & $\mathrm{Y}$ & $\mathrm{Y}$ \\
\hline $\begin{array}{l}\text { Observations } \\
\text { Pseudo R-squared }\end{array}$ & $\begin{array}{c}716 \\
0.081\end{array}$ & $\begin{array}{c}716 \\
0.115\end{array}$ & $\begin{array}{c}716 \\
0.088\end{array}$ & $\begin{array}{c}716 \\
0.122\end{array}$ & $\begin{array}{c}438 \\
0.129\end{array}$ \\
\hline
\end{tabular}

Note: The table reports regressions marginal effects. The dependent variable is reported at the top of each column. The regressions are estimated by Probit. Robust standard errors are reported below coefficients. (*): coefficient significant at $10 \%$ confidence level; $(* *)$ : coefficient significant at $5 \%$ confidence level; $(* * *)$ : coefficient significant at less than $1 \%$ confidence level. 
Table 4. Non-linear effects

Panel A: sub-sample (Size)

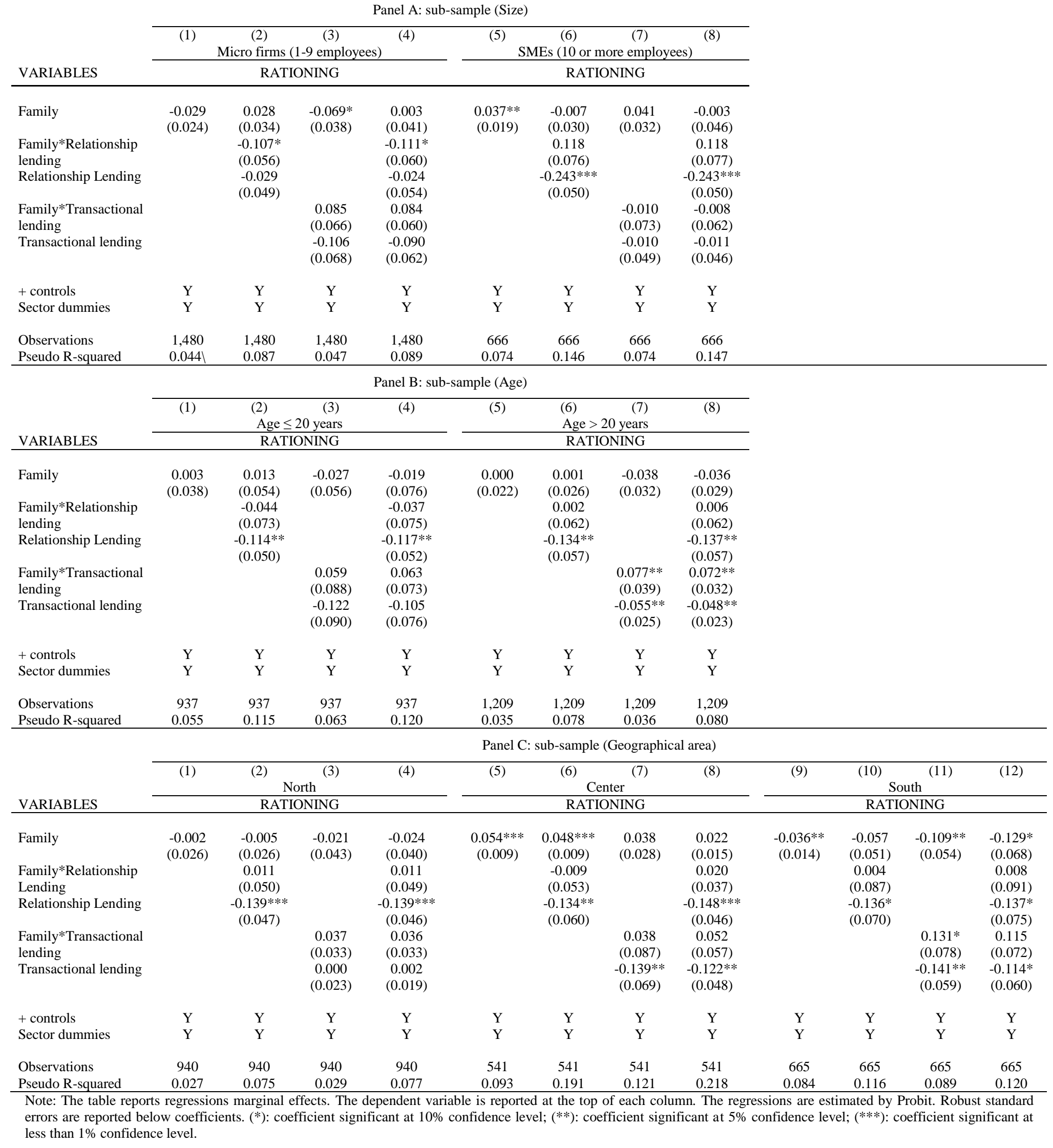


Table 5. The role of multiple banking

\begin{tabular}{|c|c|c|c|c|}
\hline VARIABLES & $\begin{array}{c}(1) \\
\text { RATIONING }\end{array}$ & $\begin{array}{c}(2) \\
\text { RATIONING } \\
\end{array}$ & $\begin{array}{c}(3) \\
\text { RATIONING } \\
\end{array}$ & $\begin{array}{c}(4) \\
\text { RATIONING }\end{array}$ \\
\hline Family & $\begin{array}{c}0.023 \\
(0.016)\end{array}$ & $\begin{array}{l}-0.056 \\
(0.044)\end{array}$ & $\begin{array}{l}0.029 * \\
(0.017)\end{array}$ & $\begin{array}{l}-0.020 \\
(0.024)\end{array}$ \\
\hline Family*One bank & $\begin{array}{l}-0.073 * \\
(0.037)\end{array}$ & & & \\
\hline One bank & $\begin{array}{c}0.002 \\
(0.034)\end{array}$ & & & \\
\hline Family*Two or more banks & & $\begin{array}{l}0.080 * \\
(0.045)\end{array}$ & & \\
\hline Two or more banks & & $\begin{array}{l}-0.002 \\
(0.034)\end{array}$ & & \\
\hline Family*One or two banks & & & $\begin{array}{c}-0.054 * * \\
(0.027)\end{array}$ & \\
\hline One or two banks & & & $\begin{array}{c}0.003 \\
(0.025)\end{array}$ & \\
\hline Family*Three or more banks & & & & $\begin{array}{l}0.058^{*} \\
(0.031)\end{array}$ \\
\hline Three or more banks & & & & $\begin{array}{l}-0.003 \\
(0.025)\end{array}$ \\
\hline Size (ln employees) & $\begin{array}{l}-0.003 \\
(0.006)\end{array}$ & $\begin{array}{l}-0.003 \\
(0.006)\end{array}$ & $\begin{array}{l}-0.000 \\
(0.005)\end{array}$ & $\begin{array}{l}-0.000 \\
(0.005)\end{array}$ \\
\hline Corporation & $\begin{array}{l}-0.005 \\
(0.018)\end{array}$ & $\begin{array}{l}-0.005 \\
(0.018)\end{array}$ & $\begin{array}{l}-0.003 \\
(0.020)\end{array}$ & $\begin{array}{l}-0.003 \\
(0.020)\end{array}$ \\
\hline Graduated & $\begin{array}{l}-0.049 * \\
(0.029)\end{array}$ & $\begin{array}{l}-0.049 * \\
(0.029)\end{array}$ & $\begin{array}{l}-0.047^{*} \\
(0.028)\end{array}$ & $\begin{array}{l}-0.047 * \\
(0.028)\end{array}$ \\
\hline Female firm & $\begin{array}{l}-0.004 \\
(0.020)\end{array}$ & $\begin{array}{l}-0.004 \\
(0.020)\end{array}$ & $\begin{array}{l}-0.002 \\
(0.021)\end{array}$ & $\begin{array}{l}-0.002 \\
(0.021)\end{array}$ \\
\hline Bank-firm discontinuity & $\begin{array}{l}0.053 * * * \\
(0.018)\end{array}$ & $\begin{array}{c}0.053 * * * \\
(0.018)\end{array}$ & $\begin{array}{c}0.058 * * * \\
(0.019)\end{array}$ & $\begin{array}{c}0.058 * * * \\
(0.019)\end{array}$ \\
\hline Innovation & $\begin{array}{c}0.021 \\
(0.013)\end{array}$ & $\begin{array}{c}0.021 \\
(0.013)\end{array}$ & $\begin{array}{l}0.026^{*} \\
(0.015)\end{array}$ & $\begin{array}{l}0.026^{*} \\
(0.015)\end{array}$ \\
\hline Export & $\begin{array}{l}-0.019 \\
(0.014)\end{array}$ & $\begin{array}{l}-0.019 \\
(0.014)\end{array}$ & $\begin{array}{l}-0.022 \\
(0.014)\end{array}$ & $\begin{array}{l}-0.022 \\
(0.014)\end{array}$ \\
\hline Growth in sales & $\begin{array}{l}-0.021 \\
(0.016)\end{array}$ & $\begin{array}{l}-0.021 \\
(0.016)\end{array}$ & $\begin{array}{l}-0.021 \\
(0.017)\end{array}$ & $\begin{array}{l}-0.021 \\
(0.017)\end{array}$ \\
\hline Regional GDP (2014) & $\begin{array}{c}-0.000 * * \\
(0.000)\end{array}$ & $\begin{array}{c}-0.000 * * \\
(0.000)\end{array}$ & $\begin{array}{l}-0.000^{*} \\
(0.000)\end{array}$ & $\begin{array}{l}-0.000^{*} \\
(0.000)\end{array}$ \\
\hline Center & $\begin{array}{l}-0.016 \\
(0.012)\end{array}$ & $\begin{array}{l}-0.016 \\
(0.012)\end{array}$ & $\begin{array}{l}-0.018 \\
(0.012)\end{array}$ & $\begin{array}{l}-0.018 \\
(0.012)\end{array}$ \\
\hline South & $\begin{array}{l}-0.028 \\
(0.025)\end{array}$ & $\begin{array}{l}-0.028 \\
(0.025)\end{array}$ & $\begin{array}{l}-0.033 \\
(0.027)\end{array}$ & $\begin{array}{l}-0.033 \\
(0.027)\end{array}$ \\
\hline Sector dummies & $\mathrm{Y}$ & $\mathrm{Y}$ & $\mathrm{Y}$ & Y \\
\hline $\begin{array}{l}\text { Observations } \\
\text { Pseudo R-squared }\end{array}$ & $\begin{array}{l}2,146 \\
0.055\end{array}$ & $\begin{array}{l}2,146 \\
0.055\end{array}$ & $\begin{array}{l}2,146 \\
0.044\end{array}$ & $\begin{array}{l}2,146 \\
0.044\end{array}$ \\
\hline
\end{tabular}

Note: The table reports regressions marginal effects. The dependent variable is reported at the top of each column. The regressions are estimated by Probit. Robust standard errors are reported below coefficients. $(*)$ : coefficient significant at $10 \%$ confidence level; $(* *)$ : coefficient significant at $5 \%$ confidence level; (***): coefficient significant at less than $1 \%$ confidence level. 


\section{Appendix}

\section{Question C3}

Compared to the financing needs expressed by your company, credit extended by the bank (or banks) was:

- Adequate (the bank has granted all the required credit)

- Not completely adequate (the granted credit amount is slightly less than the request)

- Inadequate (the granted credit amount is far below the request)

\section{Question C2}

On what grounds your firm uses no bank credit?

1. Credit application is awaiting response

2. Credit application was not accepted, even if the firm was willing to pay higher conditions

3. Credit application was not accepted, and not willing to pay higher conditions

4. Did not require credit expecting a refusal by the bank

5. Credit has been withdrawn from the bank

6. Operation / Form of funding has reached natural maturity

7. My firm does not require additional financial resources

8. Costs and tighter credit standards are burdensome

9. Financial conditions do not allow borrowing

\section{Question B4}

It could make a judgment on the ability of the bank to relate to your firm in relation to the following aspects:

\begin{tabular}{|c|c|c|c|c|c|}
\hline & $\begin{array}{l}\text { High } \\
\text { ability }\end{array}$ & $\begin{array}{l}\text { Average } \\
\text { ability }\end{array}$ & $\begin{array}{l}\text { Low } \\
\text { ability }\end{array}$ & $\begin{array}{c}\text { Insufficient } \\
\text { ability }\end{array}$ & No answer \\
\hline $\begin{array}{l}\text { Explanation of the bank costs and } \\
\text { conditions of services offered (e.g. } \\
\text { Financial services, insurance, asset } \\
\text { management, etc.) }\end{array}$ & o 1 & o 2 & o 3 & o 4 & o 6 \\
\hline $\begin{array}{l}\text { Consulting about investment } \\
\text { opportunities (e.g. Mutual funds, } \\
\text { venture capital, etc.) }\end{array}$ & o 1 & o 2 & o 3 & o 4 & o 6 \\
\hline $\begin{array}{l}\text { Consulting about national or EU } \\
\text { subsidized loans }\end{array}$ & o 1 & o 2 & o 3 & o 4 & o 6 \\
\hline
\end{tabular}




\begin{tabular}{|c|c|}
\hline Variable & Description \\
\hline Rationing & $\begin{array}{l}\text { Dummy that takes the value of one if the firm answers "Not completely adequate" or } \\
\text { "Inadequate" to question C } 3 \text {. Moreover, we consider the firm to be rationed also if it } \\
\text { answers question C } 2 \text { with the tags } 2,3,4 \text { or } 5 \text {. }\end{array}$ \\
\hline Family Firm & $\begin{array}{l}\text { Dummy that takes the value of one if the family owner has the control of the firm (more } \\
\text { than } 50 \% \text { ) and if the family owner manages the firm, and zero otherwise. }\end{array}$ \\
\hline Relationship lending & $\begin{array}{l}\text { Dummy that takes the value of one if the firm answers high/average ability to the criterion } \\
\text { "consulting about investment opportunities" of question B4, and zero otherwise. }\end{array}$ \\
\hline Transactional lending & $\begin{array}{l}\text { Dummy that takes the value of one if the firm answers high/average ability to the criterion } \\
\text { "explanation of the bank costs and conditions of services offered" of question B4, and zero } \\
\text { otherwise. }\end{array}$ \\
\hline Only one bank & $\begin{array}{l}\text { Dummy that takes the value of one if the firm has relationships with only one bank, zero } \\
\text { otherwise. }\end{array}$ \\
\hline Two banks & $\begin{array}{l}\text { Dummy that takes the value of one if the firm has relationships with two banks, zero } \\
\text { otherwise. }\end{array}$ \\
\hline Two or more banks & $\begin{array}{l}\text { Dummy that takes the value of one if the firm has relationships with two or more banks, } \\
\text { zero otherwise. }\end{array}$ \\
\hline Three or more banks & $\begin{array}{l}\text { Dummy that takes the value of one if the firm has relationships with three or more banks, } \\
\text { zero otherwise. }\end{array}$ \\
\hline Size & Log of the total number of employees. \\
\hline Age & Number of years since firm's inception. \\
\hline Corporation & Dummy that takes the value of one if the firm is a corporation. \\
\hline Graduated & Percentage of workers graduated. \\
\hline Female firm & $\begin{array}{l}\text { Dummy that takes the value of one if the firm is a female firm (more than } 50 \% \text { of managers } \\
\text { and stakeholder are women), and zero otherwise. }\end{array}$ \\
\hline Bank-firm discontinuity & $\begin{array}{l}\text { Dummy that takes the value of one if in the last two years the firm closed a relationship } \\
\text { with one or more banks, and zero otherwise. }\end{array}$ \\
\hline Innovation & $\begin{array}{l}\text { Dummy that takes the value of one if in the last three years the firm innovated, and zero } \\
\text { otherwise. }\end{array}$ \\
\hline Export & Dummy that takes the value of one if in 2014 the firm exported, and zero otherwise. \\
\hline Growth in sales & $\begin{array}{l}\text { Dummy that takes the value of one if in } 2014 \text { the firm increased their sales respect to } 2013 \text {, } \\
\text { and zero otherwise. }\end{array}$ \\
\hline Regional GDP 2014 & GDP during 2014 of the region where the firm is located. \\
\hline North & $\begin{array}{l}\text { Dummy that takes the value of one if the firm is located in the North of Italy, and zero } \\
\text { otherwise. }\end{array}$ \\
\hline Center & $\begin{array}{l}\text { Dummy that takes the value of one if the firm is located in the Center of Italy, and zero } \\
\text { otherwise. }\end{array}$ \\
\hline South & $\begin{array}{l}\text { Dummy that takes the value of one if the firm is located in the South of Italy, and zero } \\
\text { otherwise. }\end{array}$ \\
\hline
\end{tabular}

